\title{
1. The lie in the soul: Authenticity, hypocrisy, and self-deception in Rousseau
}

\author{
John M. Warner
}

A distinctive and controversial feature of contemporary democratic life is its preoccupation with sincerity. In 1970, Lionel Trilling noted our intense aversion to hypocrisy and deep admiration for those who "stay true to themselves," and in the following years several conservative critics argued that the United States had developed a navel-gazing "culture of narcissism" that mistook self-involvement for self-realization and celebrated ostentation over achievement. ${ }^{1}$ The more recent emergence of social media has only further encouraged us to display and disclose our "true selves" in ways that would have been unimaginable even a generation ago, and while it is certainly true that platforms like Facebook and Instagram make courageous acts of self-definition possible, it must also be admitted that they encourage users to foist all aspects of their lives - no matter how banal, private, or shameful - on an unsuspecting and largely uninterested group of "friends." In fact, increasing numbers of social scientists and psychologists have become concerned that social media sites that indulge our appetite for self-disclosure have contributed to an "epidemic" of narcissism and, ironically, have constructed a social reality so superficial that it denies users the opportunity to develop anything like an authentic self. ${ }^{2}$ Viewed in this unflattering light, our concern for sincerity looks more like a disingenuous justification for obsessive self-concern than a moral commitment.

Given the central but ambiguous role that sincerity plays in contemporary democratic life, it seems well worth our time to investigate the historical and philosophical bases of our commitment to this singular value. And to this end there is perhaps no better point of origin than the thought of Jean-Jacques Rousseau, who excoriates hypocrisy and otherdirectedness like no other and praises the self-consistency of human types like the classical citizen and his own fictional pupil Emile. Just as 
importantly, Rousseau not only celebrates but also enacts his commitment to sincerity, taking vitam impendere vero ("to stake one's life for the truth") as his motto and writing his autobiographical Confessions in order to provide an above all honest account of his life: "I have shown myself as I was, contemptible and low when I was so, good, generous, and sublime when I was so: I have unveiled my interior as Thou hast seen it Thyself." 3

Passages like this have led many scholars to view Rousseau as a pivotal figure in the development of the concept of sincerity and an important intellectual source of our own current fascination with it. The aforementioned Trilling, for instance, claimed that Rousseau was "uncompromising" in his commitment to sincerity, and Charles Taylor and Alessandro Ferrara both call upon Rousseau in their own defenses of "authenticity" as a social virtue. ${ }^{4}$ Joshua Cohen and John Rawls do not highlight the role of sincerity per se, but their emphasis on autonomy points in the same direction by highlighting the importance of inwardly generated virtue. ${ }^{5}$ It is, however, Arthur Melzer who most strongly emphasizes sincerity's importance in Rousseau's system, arguing not only that this virtue rests "at the deepest stratum of his thought" but also that Rousseau is at "the historical origins of our peculiar ideal of sincerity." Melzer understands Rousseau's celebration of sincerity as a condemnation of modern political thought and the licensing of narrow self-interest that it had sanctioned: though many of Rousseau's contemporaries promised that the liberation of selfishness would inspire cooperation, honesty, and mutual respect, Rousseau argued it would instead teach us how to simulate these virtues while pursuing our own good at others' expense. Thus, the birth of modern commercial society and related emergence of "bourgeois hypocrisy" furnishes the context for Rousseau's "new" emphasis on sincerity. ${ }^{7}$

Extant scholarship usefully reveals Rousseau's influence on the contemporary conversation surrounding sincerity but leaves at least two important questions unanswered. The first regards the role of sincerity beyond or outside Rousseau's concerns about the modern age: hypocrisy undoubtedly figures centrally in Rousseau's critique of modernity, but is it necessary to understand it as a vice arising only within the context of a modern commercial society? The second regards the vexed relationship between Rousseau's own words and the legacy they have spawned: though Rousseau elevates sincerity to a new and rarefied status, does his complex teaching concerning this distinctive virtue actually support the contemporary culture of sincerity in the unambiguous way that both his advocates and critics claim? 
I believe both questions must be answered in the negative, and in what follows I shall try to argue on Rousseau's behalf not only that the cultivation of sincerity is not merely an artifact of "modern" consciousness but also that our commitment to this value must be qualified by a recognition of the moral potential of self-deception. To establish these broad propositions I differentiate a series of motivationally distinct forms of hypocrisy evident in Rousseau's oeuvre (which I shall call bourgeois conformity, and subconscious hypocrisy, respectively) and analyze the severity of the moral threat posed by each. Proceeding in this way allows me to highlight four important and neglected features of Rousseau's treatment of sincerity. The first is that hypocrisy is not a monolithic but a multifaceted phenomenon. In contrast to previous scholarship that focuses on the conditions that create a specific "bourgeois" form of hypocrisy, I emphasize Rousseau's sensitivity to the incredible variety of ways in which human beings deceive both themselves and others. The second implication, related to the first, is that hypocrisy is often unconscious. Though so-called "bourgeois hypocrisy" is undertaken deliberately, Rousseau himself shows how we can be dishonest with ourselves in a variety of ways that escape our conscious notice. Indeed, he puts these dangers on display even in the lives of his exemplary characters, who despite themselves are constantly engaged in various kinds of denial, rationalization, wishful thinking, false emotional projection, and disingenuous moral negotiating in order to distance themselves from aspects of reality they are unable to accept. Third, it is necessary to recast the problem of hypocrisy as a perennial rather than a historical problem. This, of course, is not to deny Rousseau's belief that the modern age presented particularly grave threats to genuine selfunderstanding, but rather to assert that the cultivation of sincerity would remain centrally important for human beings even if the psychological distortions wrought by modernity were somehow overcome. Finally, my treatment shows that Rousseau does not treat hypocrisy as an unqualified vice or moral evil as previous scholarship so often assumes, but rather recognizes its potential usefulness. In fact, he makes the enjoyment of central human goods (e.g., romantic love) hinge on a degree of willful blindness that is difficult to square with an uncompromising commitment to sincerity.

Given these implications, a broader reassessment of Rousseau's contemporary relevance as a theorist of sincerity may be necessary. Conservative critics in particular have claimed that Rousseau's elevation of sincerity is responsible for undermining belief in moral absolutes, transforming emotional weakness into a virtue, and encouraging the kind of empty self-disclosure I began the chapter by criticizing. ${ }^{8}$ But my 
analysis reveals Rousseau's treatment of sincerity to be subtle, serious, and auto-critical in ways our cultural practice is not and to contain ample resources for criticizing the banal exhibitionism so prevalent today. It also reveals that Rousseau may be less interested in providing a doctrine of sincerity than in interrogating the problems of self-understanding and self-deception that underlie it. I therefore conclude by suggesting that we must read Rousseau's claims about the importance of cultivating sincerity in light of his warnings about the extreme difficulties that attend its cultivation.

\section{INSINCERELY YOURS: BOURGEOIS HYPOCRISY}

Though I shall be at pains to show the breadth and complexity of Rousseau's engagement with hypocrisy, it cannot be doubted that he associates this destructive vice with despicable "bourgeois" man. As both Melzer and Allan Bloom have emphasized, this new human type is for Rousseau both the product of and the decisive argument against modernity's neglect of virtue and its related unshackling of human selfishness, for though it had become fashionable for thinkers in Rousseau's time to argue that the common good was best realized through the pursuit of narrow self-interest Rousseau himself believed the bourgeois' very existence spoke forcibly against the notion. ${ }^{9}$ His social life is characterized not by cooperative and mutually beneficial relationships motivated by good faith but rather by the need to undermine others in order to do his own will. But since the bourgeois needs the cooperation of others to have his way - the very others whose interests are opposed to his own - he is forced to misrepresent himself to them. In so doing, he becomes what Melzer calls an "other-directed egoist" - one who needs others but seeks to exploit and dominate them rather than cooperate as equals. ${ }^{10}$

Before we can understand why Rousseau believed the bourgeois to be especially susceptible to the vice of hypocrisy it is necessary to understand a bit more about the social conditions that generate it. We get at least the outline of an argument in note IX of the Discourse on Inequality, where Rousseau explicitly mentions, and categorically denies, the characteristically modern idea that narrow self-interest can fashion an adequate basis for human community: "[I]f I am answered that society is so constituted that every man gains by serving the rest, I will reply that that this would all be very well if he did not gain still more by harming them." The claim here is that individuals motivated purely by instrumental considerations will always be divided by basic conflicts of interest and that one person's advancement comes at another's loss. This zero-sum 
situation is a direct function of the insatiability of self-love: because the desires that lurk within "every civilized man's heart" are ever-expanding and unquenchable, each person's pursuit of his own (infinite) interests brings him into inevitable and mutually destructive competition with others. ${ }^{11}$

A bourgeois might respond, plausibly, by arguing the tension between individual and collective good is sufficiently ameliorated by market incentives and rational institutional design, but Rousseau rejects such responses out of hand because they are grounded in a theory of self-love that does not take the drive for social recognition (amour-propre) seriously enough. Once we take proper account of this drive we get a much clearer sense of how conflicts of interest emerge and why they are so intransigent. Amour-propre, Rousseau claims, does not seek material comfort but social status, and since status is a comparative or "positional" good, all changes in its distribution have a zero-sum character. Since, that is, A's status is necessarily relative to B's, any improvement in the condition of one diminishes that of the other. Thus, Rousseau might object that insofar as the goods we seek through market exchange are desired primarily as indicators of status, economic relations do not ameliorate but rather magnify the basic conflicts of interest that he finds underneath all human relations. As long as our reasons for cooperating are informed by inflamed amour-propre - as long as we are engaged in economic exchange to enhance our social position - our fundamental interests remain in tension, and the "cooperation" we find in the marketplace is merely the initial stage in an ongoing competition for prestige. ${ }^{12}$

The fundamental conflicts of interest Rousseau finds at the basis of modern social institutions lead him to conclude that hypocrisy is a distinctly if not exclusively bourgeois vice. Indeed, for the bourgeois, hypocrisy is not an occasional and distasteful necessity but rather a comprehensive way of life. His existence is defined by the need to conceal his heart's true desire and the contradiction between what he says and what he does: hiding behind the false veil of civility and so many disingenuous "professions of good will," he spends his days seeking to deceive others into serving his interests rather than their own. His hypocrisy is so stark that what he is and what he appears to be are not only different but opposed things: "if an inhabitant of some far-off land sought to form an idea of European morals ... this stranger, I say, would guess [them] to be precisely the opposite of what they are." ${ }^{13}$

Melzer puts special emphasis on the strategic and premeditated character of bourgeois dishonesty, making the "bourgeois hypocrite" a villain motivated purely by "a calculated desire for the material benefits of being 
thought honest" and forced by his very dependence on others to conceal his sinister intentions toward them: "the egoist is forced by his very selfishness to appear just and benevolent toward others - so that they will help him - but because he is selfish, he never sincerely desires to be this way for his own sake." Even when the bourgeois keeps his word he does so for self-serving reasons - his is a sham honesty, a sunk cost of attaining the dominion over others that he desires but cannot disclose. This profound insincerity sums up what it means to be both a bourgeois and a hypocrite: "[H]ypocrisy is everywhere; it is the universal and essential characteristic of the man of our time, the modern bourgeois."14 In arguing thus, Melzer usefully emphasizes the importance of an especially destructive form of hypocrisy by highlighting Rousseau's critique of the modern effort to establish justice through narrow selfinterest. So too does he illuminate the important shaming function served by Rousseau's rhetoric of sincerity, for the demand to "look beyond our frivolous displays of good will" and take account of "what goes on in the depths of our hearts" is nothing if not a straightforward exhortation to the individual reader to level with themselves about why they do the things they do. ${ }^{15}$

Yet, to say that all bourgeois are hypocrites is not to say that all hypocrites are bourgeois, and Melzer's focus on this one form of dishonesty - however pervasive - greatly obscures the manifold and incredibly subtle ways in which human beings falsify themselves. The limited explanatory reach of the "bourgeois" account of hypocrisy becomes evident once we identify the conditions necessary for its exercise: bourgeois hypocrisy as Melzer defines it is (1) done deliberately, for the purpose of (2) taking advantage of (3) other people, who have (4) interests that conflict with one's own. It is immediately evident that many and perhaps even most instances of hypocrisy do not satisfy all these conditions. When, for instance, we lie to others, we often do so for reasons that have nothing to do with our economic interests or the hope of gaining "material benefits." Thus, in our anxious quest for recognition we misrepresent ourselves not simply to gain power over others but also to win their approval and esteem. Note, too, the questionable presumption that bourgeois falsification involves a concealment of one's malign intentions from other people only - we lie to others to extract resources, but have no evident need or tendency to lie to ourselves. Once again, Rousseau knew better: he understood that human beings are astonishingly creative self-deceivers and utilize a number of subconscious techniques (e.g., denial and rationalization) in order to justify their behavior or to render some unpleasant feature of reality more tolerable. The subconscious character of these techniques points to the incredible 
difficulty of cultivating sincerity, for they point to the existence of concealed and complex drives that must be identified and then consciously mastered (or at least managed). Sincerity, conceived in this broader way, involves not merely the absence of dishonesty but also the presence of self-awareness.

These lines of criticism are too general to be entirely persuasive, but they provide some prima facie reasons for thinking that the bourgeois theory of hypocrisy developed by Melzer and Bloom requires amendment and addition to be persuasive. Thus, in the analysis to follow I seek to reveal the richness and nuance with which Rousseau treats the phenomenon of hypocrisy, seeking particularly to reveal (contrary to the bourgeois hypothesis) that human beings lie to themselves as often as they lie to others, and that when they do lie to others they do so in order to gain acceptance rather than establish dominion.

\section{CONFORMITY HYPOCRISY}

We have seen that in order to explain Rousseau's account of the prevalence of hypocrisy it is necessary to give at least passing attention to amour-propre's role in magnifying the conflicts of interest that structure our political and economic relations. And while Melzer does not name amour-propre it is clear that this singular passion is the origin of bourgeois hypocrisy, for since its drive for superiority causes the desire to dominate so too does it cause the self-falsification that such domination requires. ${ }^{16}$ But this conception of amour-propre and the hypocrisy to which it gives rise is misleadingly simple, for it wrongly assumes that our reasons for dishonesty can be reduced to the hope of gaining social power and its attendant "material benefits." This narrowing of the motivational field does not do justice to amour-propre's complexity and consequently neglects the other, and equally powerful, reasons we have for misrepresenting ourselves in everyday life. Rousseau notes in a variety of contexts that amour-propre craves more than dominion over others, and that human beings lie to others not only to satisfy their tyrannical lust for power but also to gain love and esteem from their fellows. ${ }^{17}$

Perhaps the most obvious type of hypocrisy that emerges from the desire for approval is a willingness to conform to standards that one does not understand or endorse, and this willingness is often born of a desire not to dominate but rather to submit to the will of another. We all want to be loved, and to gain what we so crave we are often led to do and say things that we ourselves believe to be wrong. The tendency to abandon 
our own principles and values in pursuit of social acceptance is an important source of mischief in Rousseau's moral universe, and his attentiveness to this kind of self-falsification is surely part of the reason that "conformity" is now considered such a bad word. But here we must pause and ask: what, exactly, is wrong with conformity?

One radical possibility is that proposed by J.S. Mill, who argues that thoughtless adherence to any social norm, even a sensible one, is bad because it diminishes the distinctively human capacity for autonomous choice. In On Liberty, Mill inveighs against the "despotism of custom" because of its tendency to stifle the "human faculties of perception, judgement, discriminative feeling, mental activity, and even moral preference," and claims that whoever allows the outside world to determine his plan of life has no need of any power save the "ape-like one of imitation." ${ }^{18}$ Conformity is for Mill not a venal but a mortal sin involving the renunciation of our highest and best capacities: when we passively accede to others' opinions we slavishly allow the external world to determine the form and substance of our identity. Such a surrender of agency is not mere intellectual weakness but positive inhumanity, representing an abdication of the liberty that defines and ennobles us as a species. Mill's radical notion of freedom shows us not only why conformity is a vice but also why sincerity is a virtue - nay, the virtue for it holds that the validity of a plan of life is primarily determined not by its content but rather by the extent to which its adoption is internally motivated. When, that is, we are considering the choiceworthiness of a plan, the question to be answered is not one of social appropriateness ("Will others approve?") or even ethical correctness ("Is it upright?"), but rather of authenticity ("Does it express my sincerely held beliefs?"). The most fully realized human life is the one lived in accord with inwardly generated and sincerely held values, not the one lived in accord with objectively true values.

In his account of Rousseauan sincerity Melzer absorbs the Millian account in toto, arguing that Rousseau and not Mill is the original fount of our present-day "obsession" with "being oneself." For Melzer, Rousseau is the first to replace "the traditional vocabulary of vice and virtue with new pairs of opposites such as inner-directed/other-directed, real self/alienated self, [and] sincere/hypocritical." Such an argument is "something new" because it makes sincerity "an end in itself" and "define[s] the good as being oneself regardless of what one may be."19 Melzer does concede that "strict honesty or sincerity is not wholly compatible" with a variety of lives Rousseau himself considered exemplary - most especially Rousseau's own life as a philosopher - but this does not prevent him from concluding that "the ideal of sincerity" exists 
at "the deepest stratum of Rousseau's thought." 20 This is a remarkably strong claim, but it is also a serious one: in his autobiographical works Rousseau often appeals to the sincerity of his intentions in order to excuse the moral failings he so candidly recounts, and in his political and social writings he rails against the dangers of depending on others' opinions and emphasizes how "staying true" to ourselves can help prevent the moral corruption that comes with such dependence. Such emphases lead Trilling to join Melzer in believing that sincerity is for Rousseau a kind of ethical meta-criterion that applies across the political, psychological, and even aesthetic domains: "Rousseau is concerned to foster a human type whose defining characteristic is autonomy, the will and strength to make strict choice among the elements of our enforced life in society." 21

Though Melzer's and Trilling's (very different) readings of Rousseau converge on the central finding that sincerity is an "end in itself," Rousseau's own position is not so straightforward. Indeed, Rousseau does not criticize false conformity in the name of emancipated individuality as does Mill, but rather in the name of aggrieved virtue. When he complains in the First Discourse that "it is customs that are followed, never one's own genius," his concern is not that we too passively accept conventional morality but rather that we too cavalierly disregard it. ${ }^{22}$ Much of the reason that Rousseau seeks to reserve the arts and sciences for a select few is because he doubts that people are as a rule capable of the intellectual and moral independence that their practice demands, and he believes that most of us would be more fully realized if we believed and behaved as customary morality required. ${ }^{23}$ This is, of course, not to say that Rousseau denies that inwardly guided self-realization of the kind Mill advocates may be a path to virtue, and a noble one at that, but it is to say that he stops short of claiming that free experimentation with one's identity is "an end in itself" or somehow constitutive of virtue.

As the argument of the First Discourse develops it becomes increasingly clear that conformity is problematic because it destroys civic virtue, and this point emerges with special clarity when the question of the artist's relationship to society is raised. All artists understand the challenge of maintaining the integrity of their creations before a fickle and often uninformed crowd, and Rousseau accuses many of his contemporaries - most notably, Voltaire - for all too willingly conforming to aesthetic ideals they know to be impoverished: "[T]ell us, famous Arouet, how much you have sacrificed the manly and strong beauties to our false delicacy, and how much the spirit of gallantry, so fertile in petty things, has cost you great ones?"24 Rousseau seems to be criticizing Voltaire for deviating from his vision and engaging in an inauthentic vulgarization of 
his art, but in the context of the First Discourse's larger argument it is clear that Voltaire's hypocrisy is blameworthy for moral as well as artistic reasons. The problem is not merely that Voltaire lowers himself to be understood but rather that, after doing so, he makes no effort to raise his audience up. Rousseau blames the artist who happily debases himself for a few cheap laughs because he is complicit in the moral corruption of his audience, not because he is willing to sacrifice the purity of his art.

In the Letter to M. D'Alembert, Rousseau would once again accuse Voltaire of conformity hypocrisy but would train his sights on Molière, who is said to have composed "reprehensible plays" written to indulge rather than reform corrupt moral taste. Of course, Rousseau himself understood the difficulty of writing for a corrupt public and sympathetically identifies with the challenge Molière - both a "decent man" and a true genius - had set for himself. All great artists must understand the conventions they seek to transcend, and those who seek to educate their audience without also entertaining them will be summarily dismissed as sermonizers and hamfisted bores. ${ }^{25}$ Rousseau nonetheless persists in condemning Molière for bowing too deeply to his public and for conforming to its corrupt taste without also trying to transform it. The Misanthrope, Rousseau says, needlessly flatters its audience by celebrating the charming but despicable Philinte at the expense of the dour but virtuous Alceste, taking every opportunity to exaggerate the virtues of the former and the vices of the latter. And Molière's gravest sin is not that he fails to understand Alceste's character but rather that he deliberately falsifies it in order to gain the approval of his audience: Rousseau claims that Molière did not share his audience's impoverished taste, for having "emancipated himself" from the bad morals of his age Molière was so identified with Alceste that "many have thought that he wanted to depict himself." Nonetheless, the playwright's inability to moderate his appetite for applause led him to deform Alceste and misrepresent his "dominant passion" so as to make him not only "irritable and bilious" but also petty, childish, and vengeful. Molière so needed the applause of others that he would corrupt them to get it. ${ }^{26}$

The pressure that forced Molière to conform to the expectations of his audience may be felt with special acuity by artists but is hardly isolated to them. The desire to please is present across the entire field of social interaction and threatens to turn all of us into fakers, fabricators, and passive instruments of others' wills. It is, however, felt with special intensity in the sexual domain, where lovers who aspire to do right by each other instead become the unwitting catalysts of each other's corruption. The emergence of love is a profoundly destabilizing moment in the life of a self that aspires to authenticity because it requires 
emotional dependence of an especially deep and dangerous kind. ${ }^{27}$ Ideally, of course, such dependence will not diminish but rather enhance our individual agency and power - that is, in fact, love's most fundamental promise, and Rousseau emphasizes that our own self-realization and authentic humanness depend on our willingness to seek its fulfillment - but in the pursuit of romantic recognition we risk sacrificing our most cherished convictions and alienating our most fundamental powers. In Emile, Jean-Jacques consistently worries that his pupil will, in quest of a beloved, lose himself, and while this danger is (as we shall see) ultimately obviated by the presence of an omniscient tutor it comes to define the relationship between Julie and Saint-Preux, the star-crossed lovers whose illicit romance is the subject of Rousseau's epistolary novel La Nouvelle Heloise (henceforth called Julie). Unlike Emile and Sophie, Saint-Preux and Julie do not have adequate social supports and must navigate the many challenges they face more or less on their own. The results are predictably ruinous: after their secret courtship is discovered and forcibly terminated by Julie's father, who is furious with his daughter for accepting the affections of a bourgeois, Saint-Preux is banished under threat of death and Julie is forced to wed another man.

It is important to note that before their separation the lovers frequently waxed poetic about the beauty of virtue and the importance of sexual monogamy to love. ${ }^{28}$ Indeed, they believed their shared convictions on this score were an essential and ineliminable basis for their union: Saint-Preux, for instance, once gravely intoned that "if I must choose between honor and you, my heart is prepared to lose you: it loves you too much, O Julie, to preserve you at that price."29 Following their separation, however, when they must choose between what virtue requires and what love demands, these high ideals quickly vanish: Saint-Preux goes to Paris and visits a prostitute and both lovers, morally drained by their forced estrangement, agree to resume their clandestine romance. "Nature, O sweet Nature, take back all thy rights! I abjure the heartless virtues that obliterate thee," an exhausted Julie proclaims to a delighted Saint-Preux, who not only commends but seeks to justify Julie's resolution. He hypocritically appeals to moral principles that both he and his lover reject in order to preserve a relationship they cannot sincerely defend: "[W]hy," he disingenuously asks, "should we alone wish to be better than all the rest of mankind, and subscribe with childlike simplicity to illusory virtues that everyone talks about and no one practices? ... [A]ll the honorable people [in Paris] would chuckle at the man who out of respect for marriage resisted his heart's penchant." While Saint-Preux does confess to despising himself for advancing principles he knows to be wrong and exhibits some awareness of the extent of his self-alienation 
("I know not what I write"), these reservations do not prevent him from trying to regain the love that had been taken away. In the pursuit of his heart's desire he has become so alienated from his deepest convictions that he is willing to say and do virtually anything to make Julie's wish a reality: he "loathes" the principles he enunciates "without being able to counter them," and goes on, desperately searching for a rule that might justify his heart's desire, to confusedly insist that in resuming their relationship they "shall be criminal, but ... shall not be wicked." Though Julie's marriage to Wolmar, along with her mysterious (and largely disingenuous) "conversion," prevents the resumption of a romantic relationship, Saint-Preux's hypocrisy could not be clearer. He is engaged in a deeply disingenuous form of moral negotiation both with Julie and himself, and is willing to abandon any and all of his scruples in order to regain, if only for a moment, his beloved. ${ }^{30}$

With the recognition of others' wills comes the desire to conform to them, and with the desire to conform comes the danger of agency surrender. We have seen that this form of hypocrisy is a pervasive source of mischief in Rousseau's moral universe, leading artists to abandon what is highest and best in their creations and lovers to neglect the virtues that form the basis of their union. Attention to this kind of self-falsification points up two important limitations in Melzer's discussion. First, it shows that the motivational bases for hypocrisy are more complex than the "bourgeois" hypothesis supposes: people are dishonest for all sorts of reasons, and they fabricate identities not only to dominate but also to submit to others' wills. Second, it reveals that hypocrisy is not the exclusive preserve of the comprehensively corrupt bourgeois and the culture of dishonesty he has created, as Melzer's discussion often suggests, but is rather a persistent and omnipresent threat even in the lives of exemplary human beings like Molière and Saint-Preux.

\section{DENIAL AND RATIONALIZATION: SUBCONSCIOUS HYPOCRISY}

Though "bourgeois" and "conformity" hypocrisy differ in their motivational bases, they are both interpersonal forms of deception that are undertaken more or less deliberately. But there is no reason to think hypocrisy requires the presence of a self-other conflict, and in fact some of the most serious challenges to the cultivation of sincerity come not from outside but rather from within the self. If Rousseau emphasizes anything about sincerity, it is that it involves a transparent self-relation that is extraordinarily difficult to establish and maintain. 
The difficulty stems in part from the human being's nearly limitless capacity for self-deception: we use all kinds of subconscious techniques to distance ourselves from hard truths, and unless we can identify and manage these techniques we shall never make any progress in the quest to discover our "true" selves. Melzer, however, blots out these sizable difficulties in his effort to assimilate Rousseau to the contemporary "cult of sincerity," and in so doing often makes him sound more like a new age charlatan than a serious thinker. His Rousseau assures us that subjecting our beliefs to "rigorous dialectical examination" or undergoing "psychoanalytic examination of the unconscious mind" are unnecessary steps on the path to enlightenment, that the magic of introspection can effectively substitute for the hard work of understanding and mastering our own drives, and that merely by meditating on the "real me" that exists outside "society" the obstacles to self-knowledge will somehow vanish. ${ }^{31}$ Rousseau, of course, knows that the business of knowing oneself is far more difficult than this, and part of the reason for the difficulty is the presence of subconscious forces that lead us to falsify ourselves without our even realizing it.

\section{Denial}

One such force is the tendency to reject the truth or the existence of things we find hateful, and Rousseau thinks this tendency so pronounced that he believes that even the impeccably educated Emile is susceptible to it. Interestingly, the circumstances that challenge Emile's commitment to sincerity look rather like Saint-Preux's: his courtship is interrupted by an outside authority and, though he and his beloved Sophie are eventually wed, they are allowed to do so only after a two-year separation following their engagement. Emile is, of course, intensely resistant to the idea of being separated from his beloved and, as a way of preventing it, engages in a variety of rather disingenuous moral negotiations with both his tutor and himself:

Uncertain, troubled, and eager to know what I am getting at, Emile fearfully questions me ... "What must be done?" "That which must be done!" I answer him in a firm tone: "You must leave Sophie." "What are you saying?" he shouts with anger. "Leave Sophie! Leave her, deceive her, be a traitor, a cheat, a perjurer ...! What!" I respond, interrupting him. "Is it from me that Emile is afraid of learning to merit such names?" "No," he continues with the same impetuosity. "Not from you nor from another. In spite of you, I shall know how to preserve your work. I shall know how not to merit those names." 32 
Though Emile does not know how to lie to others he has clearly acquired the art of self-deception. He is showing all the signs of a person in deep denial about the reality of his situation, and this denial manifests itself in a dishonest interpretation of his tutor's words. He cannot possibly think Jean-Jacques wants him to "leave" Sophie forever, for the couple had just gotten engaged thanks in large part to his tutor's efforts, but in his anger he gives Jean-Jacques' utterance a sinister meaning that it does not carry to justify his rebellion. Even after being corrected he continues to argue with Jean-Jacques about his fate, pressing whatever argument he can to persuade his tutor (and himself) that leaving Sophie is not necessary. Because Emile is self-deceived and does not recognize his denial for what it is, it is necessary for Jean-Jacques to intercede and command his pupil to stay true to himself: "[S]ince you do not obey reason," he tells his pupil, "recognize another master. You have not forgotten the promise you made to me. Emile, you have to leave Sophie. I wish it."33 Jean-Jacques reminds Emile that since he voluntarily submitted to his tutor's authority, he is bound to obey not by interest nor even by love, but rather by the steadfast declaration of his own will, and to break a promise one makes to himself is to be a hypocrite of the worst and most objectionable kind. ${ }^{34}$ Were it not for the tutor's willingness to exercise his authority, however, Emile's susceptibility to a subtle form of selfdeception would have undermined his education at a key moment in its development.

\section{Rationalization}

Denial is certainly a pervasive form of self-deception, but it is far from the only snare we set for ourselves. When we find ourselves in dilemmas like Emile's we are prone not only to deny inconvenient truths but also to misrepresent, to both ourselves and others, our reasons for undertaking or wanting to undertake some course of action. We call this kind of misrepresentation rationalization, and the danger it poses to selfunderstanding deserves emphasis because of its special relevance to the age of enlightenment in which Rousseau lived and of which he was so critical. Rousseau believed his was a time of profound, and deluded, self-congratulation, one in which his fellow philosophers were so busy patting themselves on the back that they had turned a blind eye to the considerable moral costs created by their ersatz progress. He believed such blindness to be hypocritical because partially willful: it was sustained and nurtured by a prideful unwillingness to reconsider what it meant to understand oneself and one's relation to the world. Rousseau's execrations of philosophy are many, but perhaps none better highlight its 
connection with hypocrisy than the Discourse on Inequality's attack on "the philosopher" who Rousseau chastises for putting "his hands over his ears and argu[ing] with himself a bit" in order to stifle his sense of pity and ignore the injustices occurring around him. ${ }^{35}$ Such actions certainly suggest an evident lack of sincerity - the philosopher is not reasoning but rationalizing. His internal deliberations are disingenuous, and the considerations preventing him from acting are different from the reasons that might justify inaction. Thus, when he chooses to question rather than act upon the natural sentiment that "rebels within him," we have a sense that a conclusion has been reached well in advance of any honest selfinterrogation: he is using philosophy not to search for truth but to excuse his own moral laziness.

But the philosopher's self-deception appears to run deeper than this: his failure of sincerity is not simply that he is reasoning dishonestly but that he is attempting to reason at all. As the context of the example makes clear, the natural foundation for morality is not reason but pity, and this "first feeling of humanity" will provide the philosopher with the situational guidance he needs if he would but consult it. But even in an "easy" case where no philosophy is needed to determine what ought to be done, everything in the philosopher "rebels" against giving sentiment priority over reason: much like the man who thinks the world is made of nails because he happens to have a hammer, so the philosopher is determined to view the tool he has - the ability to reason - as the solution to the problems he faces. To the degree this is true, the philosopher is possessed of a form of "false consciousness" and, as such, will find himself unwittingly complicit in his own falsification. ${ }^{36}$ The harder he tries to understand himself and his obligations to others, the more puzzling and inscrutable such questions will become.

Self-serving rationalizations are hardly the exclusive domain of the philosopher. Indeed, Rousseau believes we are all susceptible to dishonest self-dealings like this, and in Julie he mercilessly and unsparingly demonstrates how more sympathetic (if equally misguided) characters seek to use reason in order to justify behaviors they themselves know to be wrong. Saint-Preux is the most egregious offender in this regard, and is at his rationalizing worst following his separation from Julie. After he learns that his beloved marries another man he continues to drift even further from his authentic self, engaging in still more motivated reasoning and rationalization as ways of distancing himself from the pain caused by the forced separation. Soon after Julie's wedding he writes to his friend Edward Bomston - himself hardly a paragon of self-knowledge - and says he would like to kill himself. In order to justify this 
conclusion, he rehearses a series of dishonest and unconvincing arguments that read more like cries for help than anything resembling philosophy.

There is some evidence that Saint-Preux is at least partially aware, if only partially aware, of the insincerity of his argument. ${ }^{37} \mathrm{He}$ tries, for instance, to distance himself a bit from the arguments he makes by explaining that he is consciously imitating another writer. Assuming this passively imitative posture allows him to make his case without fully accepting it as his own, and to advance the paradoxical if not entirely unreasonable suggestion that imitating another may help him rediscover himself. The entire exercise, however, is an abject failure, with SaintPreux quickly becoming persuaded by his own rhetoric and lapsing into the kind of transparently self-righteous sanctimony utilized by the Discourse on Inequality's insincere philosopher. In a revealing turn, he accuses the opponents of suicide of precisely the vice he is exhibiting, namely the tendency to argue insincerely: "Milord, these declaimers are not in good faith. Absurd and cruel in their reasonings, they make the alleged crime worse as if one were ending one's existence, and punish it, as if it still existed." 38

Bomston is both unpersuaded and offended by his friend's disingenuousness, and in a forceful if somewhat bumbling display of the power of friendship he seeks to recall his friend to his former self. In accusing Saint-Preux of abandoning those who need him, of being misled by his emotions, of being narcissistically fixated on his own grief, and of arguing in bad faith, Bomston seeks to restore his friend to some measure of sanity by emphasizing the contrast between what he was and what he has become:

$[$ F]ormerly I found sense, truth, in you ... What have I now found in the reasonings of this letter you seem so smug about? A miserable and perpetual sophism which by the distractions of your reason indicate those of your heart, and which I would not even bother pointing out had I not taken pity on your ranting. ${ }^{39}$

Bomston asks Saint-Preux to remember who he used to be and to look, from the perspective of his former self, upon who he now is. This spectatorial technique is meant primarily to help his friend rediscover the virtues that made him estimable but it also suggests that insofar as Saint-Preux wants seriously to entertain the idea of suicide, the appropriate perspective is the subjective one attained by the "authentic" self rather than the detached "view from nowhere" that Saint-Preux seeks through philosophical contemplation. If, that is, there is an appropriate 
justification for suicide, it needs to emerge out of values that Saint-Preux has long embraced and can sincerely affirm as his own, not from disingenuous ad hoc speculations with no meaningful relation to his moral identity. Sincerity of a kind clearly not present in Saint-Preux's letter would thus seem to be a necessary if not sufficient condition for a successful "right to die" argument.

Insofar as this is the case, Bomston's reply is noteworthy not simply because it seeks to restore Saint-Preux to a previous and presumably more authentic version of himself but also because it reveals that Saint-Preux himself does not grasp the depths of his own falseness. Saint-Preux does seem aware that the specific arguments he makes are somewhat disingenuous, but there is no obvious reason to think that his turn to argument itself is anything other than a good faith effort to gain much-needed critical distance from his situation. He seems, that is, to sincerely believe that philosophy can help him understand what he may and may not permissibly do with his own life. But Bomston sees something insincere in Saint-Preux's very desire to philosophize and argues that it is a product of emotional needs that his friend refuses to acknowledge. His concern, which Rousseau himself reiterates in an editorial note, is not merely that Saint-Preux's arguments are self-serving rationalizations - though they surely are - but rather that his attempt to conceive of his problems as somehow philosophical is itself an act of self-deception. ${ }^{40}$

It is, of course, easy to understand why Saint-Preux would want to suppress from his conscious mind truths that he finds overwhelmingly painful, and viewing his misery through a philosophical lens allows him to do this both by temporarily distracting himself from the pain of being spurned and by reframing his suicide as an act motivated by philosophical principle rather than emotional weakness. Such self-deception may ease Saint-Preux's psychological pain, but Bomston sees through the subterfuge and urges his friend to deal more honestly with himself. When he accuses his friend of substituting "the distractions of ... reason" for those of sentiment he is exhorting him to view his plight not as a philosophical dilemma with a formal solution but rather as an emotional wound that, given time, will heal of its own accord. Saint-Preux's problems are on Bomston's accounting not complex or weighty enough to require philosophical treatment - one may as well philosophize about what to eat for breakfast - and the philosophical turn he takes is a way of misrepresenting to himself what his reasons for suicide actually are. 


\section{SELF-DECEPTION AND THE RE-ENCHANTMENT OF THE WORLD: HYPOCRISY AS A VIRTUE?}

Though we have been at pains to understand the irreducibly plural nature of Rousseauan hypocrisy, all the forms surveyed so far have at least one feature in common: they are all blameworthy. But does self-falsification necessarily suggest deep character deficiency? Though we would certainly expect Rousseau to answer in the affirmative - at least if Melzer, Trilling, or other conventional analyses are to be believed - a rapidly growing body of empirical evidence ${ }^{41}$ suggests the ability to self-deceive has manifold psychological and social advantages that are not easily ignored. Starek, for instance, has shown that high achievers routinely lie to themselves in a variety of ways in order to spur themselves to ever-greater attainments, and Sackeim has pointedly suggested that without the ability to self-deceive human life might be intolerably painful: "[W]e are so susceptible to being hurt that we're given the capacity to distort as a gift." ${ }^{2}$ If we take seriously the idea that unrelenting self-honesty might inspire a dark fatalism and all the moral passivity it implies, then it makes sense to wonder whether Rousseau's rejection of hypocrisy is in fact as categorical as is often believed.

Interestingly, Rousseau proves to be surprisingly sensitive to the potential benefits of self-deception and even argues for its importance to cultivating virtue. As a way of seeing this connection it is helpful to recall that Rousseau, as Melzer and other Straussian commentators have noted, rejected the modern idea that political community could subsist in the absence of virtue but simultaneously radicalized the modern claim that a concern for virtue is not natural to human beings. ${ }^{43}$ In arguing thus, he puts himself in the difficult position of defending virtue's importance while also recognizing its unnaturalness. How, then, to compensate for what nature does not provide?

Rousseau's answer, in short, is that in order to love virtue we must create illusions for - that is, lie to - ourselves. More specifically, he believes the imagination, and in particular the sexual imagination, might effectively stand in for nature, and Emile puts particular emphasis on the moralizing power of love while also noting its artificiality. ${ }^{44}$ Rousseau repeatedly and openly claims that true love necessarily involves some degree of more or less willful self-deception because it is based on a false projection of perfect qualities onto a decidedly imperfect human being:

And what is true love itself if not chimera, lie, and illusion? We love the image we make for ourselves far more than we love the object to which we apply it. If we saw what we love exactly as it is, there would be no more love 
on earth. When we stop loving, the person we loved remains the same as before, but we no longer see her in the same way. The magic veil drops, and love disappears. ${ }^{45}$

The ability to perceive reality in its stark and horrid clarity is anathema to romantic enthusiasm, and romantic enthusiasm is necessary to the cultivation of both virtue and the sense that one's life is meaningful. Thus, though "in love everything is illusion," the false beliefs it creates are salutary insofar as they "suffuse our heart with all the virtues" and allow for a livelier and more vivid experience of the sentiment of our existence. ${ }^{46}$ So, although Emile's beloved Sophie will in fact never be nearly so perfect as he imagines her to be (nor will he compare favorably to Sophie's imaginary hero Telemachus), Rousseau claims the false beliefs that lovers have about each other ought to be respected because they make the experience of a central - perhaps the central - human good possible. ${ }^{47}$

But here it might be objected that the experience of love need not involve any self-deception. There is, after all, a significant difference between treating a known falsehood as a truth and believing sincerely in the truth of something that turns out to be false, and Emile and Sophie appear sincerely persuaded of each other's basic perfection. ${ }^{48}$ However, it is important to remember that we readers are informed in ways that Emile and Sophie are not and as recipients of Rousseau's peculiar teaching on romantic love, we know that the enjoyment of a fundamental human good and the realization of our highest capacities depend decisively on our ability to surrender to the illusions of love while recognizing their illusoriness. Thus, a full embrace of Rousseau's teaching would seem to require his readers deliberately to cultivate beliefs within themselves that on some level they know to be untrue.

Though it is tempting to think the necessity of self-deception is limited to the romantic domain, Rousseau himself argues that the capacity to imaginatively project beauty onto intrinsically unbeautiful objects may have more general application. In fact, developing this talent may be of particular use in helping modern readers reinterpret their relationship to nature. It is clear that Rousseau, though himself a believer in modern science, nonetheless thought that efforts to apply its insights to politics had diminished his readers' sense of possibility by reducing all human behavior to the laws of matter in motion and the promptings of narrow selfishness. ${ }^{49} \mathrm{He}$ argues that modern political science's reductive account of human nature is one of its greatest weaknesses, and that the ancients' ignorance of the natural world was morally empowering because it liberated their moral imagination. Where moderns appeal only to force, 
self-interest, and the "vain rigor of the laws" in order to ensure fidelity to the law, ancient peoples ${ }^{50}$ inspired lawfulness by cultivating a sense of awe and mystery: "[B]efore force was established, the gods were the magistrates of mankind. It was in their presence that individuals ... uttered their promises. The face of the earth was the book in which their archives were preserved." Through the power of pure imaginative projection the ancients dreamed up an enchanted world populated with gods, spirits, nymphs, fairies, and other mysterious and unseen intimations of the divine. In so doing, they managed to invest inert lumps of matter "stones, trees, [and] heaps of rock" - with poetic and moral significance and create for themselves a social landscape conducive to virtue. This thoroughly poetized (and completely imaginary) account of the natural world contributed to the ancients' moral superiority over the moderns, for when contracts and other human artifice are imbued with transhuman significance they acquire a "sacred" and "venerable" character they would otherwise lack. ${ }^{51}$

For all his praise of the ancients' edifying view of nature, Rousseau knew it to be false and was himself engaged, albeit with reservations, in the Enlightenment attempt to demystify the natural world. ${ }^{52}$ Thus, though the extent to which Rousseau accepted the materialistic philosophy of, say, Hobbes, is not entirely clear, it is clear that he thought the growing influence of this philosophy precluded the possibility of a return to the naïve enchantment of premodern times. Here as everywhere, Rousseau staunchly rejects the possibility of going backward. Thus, modern man seems to be caught in a kind of tragic situation: his virtue and happiness demand a poetic rendering of nature, but the nature he has discovered is decidedly unpoetic. What, then, to do?

The answer to that question would seem to depend on the human capacity to believe in its own illusions, for as with romantic love we must through the exertions of our own moral imagination find a way to wrench edification and meaning from phenomena that are indisposed to grant them. Indeed, I submit that Rousseau himself is engaged in precisely this process in his own presentation of nature and seeks to beautify that which is intrinsically unbeautiful: he poetizes humanity and the natural world not by neglecting but rather by radicalizing their brutishness and deploys a number of rhetorical strategies in order to re-present a fundamentally purposeless and violent state of nature as an idyll. ${ }^{53}$ One such strategy, as Scott has perceptively noted, is the repeated use of visual language: Rousseau often begins depictions of the state of nature by saying "I see." 54 This visual language underscores the imaginary character of Rousseau's state of nature by emphasizing what he "sees" in his mind's 
eye, but it also encourages the reader to reconsider the bounds of moral possibility by inviting him into the process of moral envisioning.

In Emile, too, Rousseau indicates that there is a fictive or imaginary quality to his argument:

$[\mathrm{O}]$ ne no longer studies, one no longer observes, one dreams; and we are gravely presented with the dreams of some bad nights as philosophy. I will be told that I, too, dream. I agree; but I give my dreams as dreams, which others are careful not to do, leaving it to the reader to determine whether they contain something useful for people who are awake..$^{55}$

Now, when Rousseau characterizes his project as a "dream" this does not mean that he disbelieves it or that it should not be taken seriously as philosophy. What I think he means here, at least in part, is that in order to fully embrace the beliefs necessary to our virtue and happiness it may be necessary to distance ourselves from potentially disquieting truths about ourselves and the natural world and put emphasis, instead, on nature's more edifying features. In order to do this, we must be prepared to act as if beliefs that might not be true in fact are and as if certain features of reality do not exist when they, in fact, do. It may go too far to say that these kinds of psychological gymnastics involve "hypocrisy," but it is not implausible to think that they involve a bit of self-deception. Focus, after all, requires temporary blindness.

\section{CONCLUSIONS}

"Know thyself." These words, famously inscribed at the Temple of Delphi and made immortal by Socrates' apology to the Athenian assembly, have exhorted those who would seek to know more about the world to begin by looking within themselves. Few thinkers took this imperative more seriously than Jean-Jacques Rousseau, who launched his philosophical career by admonishing his contemporaries for their neglect of this most essential art: the First Discourse begins by noting that though modern men had made extraordinary advances in their understanding of the external world they remained unable to make any progress in the "grander and more difficult" task of understanding themselves, and the Second Discourse opens with the still more disquieting suggestion that we have not even begun to understand the obstacles attending the process of self-knowledge. ${ }^{56}$

Rousseau's novel theory of human nature, coupled with his desire to help readers understand themselves in light of his theory, led him to prioritize the virtue of sincerity or authenticity in ways that previous 
political thinkers had not. Rousseau scholars have sought to make sense of his emphasis on sincerity by emphasizing the emergence of historical and structural factors that have distorted the self-relation: the emergence of commercial society, the ascent of narrow self-interest, and the increased influence of philosophical materialism - developments Rousseau associates with "modernity" - had multiplied our desires while diminishing our sense of possibility, and had turned us all into liars, frauds, cheats, and fakes. The preceding analysis, however, has shown that this approach is useful only in a limited way, and unjustly neglects the hidden psychological impediments to self-knowledge: the deep selfopacity of sympathetic and even exemplary characters like Emile and Saint-Preux shows us that even if we somehow overcame the dislocations wrought by modernity we would still remain obscure to ourselves in a very basic sense. Denial, rationalization, self-aggrandizement, wishful thinking, and other forms of self-deception cannot be understood as creations of this or that historical epoch but rather as necessary products of the social situation. They are built into the structure of subjectivity and, as such, are as perennial and immutable as the conscious self.

Reflections like these simultaneously reinforce and problematize the proposition that Rousseau is at the origin of the contemporary concern with sincerity - reinforcing because they show the self-relation to be fundamental and problematic because they show Rousseau to be an uncooperative member of "the cult of sincerity." In order to be one's "true self" one must first understand what that self is, and perhaps the only constant in Rousseau's remarkably varied presentations of the search for self-understanding is that the subject is inevitably left in aporetic confusion. Insofar as this is the case, we may do better to view Rousseau's call to introspection less as a solution to the problem of sincerity than a statement of the problem itself.

\section{NOTES}

1. Trilling, Sincerity and Authenticity; Lasch, The Culture of Narcissism; Sennett, The Fall of Public Man; Bell, The Cultural Contradictions of Capitalism.

2. Carpenter, "Narcissism on Facebook"; Twenge, Generation Me.

3. Rousseau, The Confessions and Correspondence.

4. Trilling, Sincerity, 57; Taylor, The Ethics of Authenticity; Ferrara, Modernity and Authenticity.

5. Rawls, Lectures on the History of Political Philosophy; Cohen, A Free Community of Equals; cf. Reisert, "Authenticity, justice, and virtue in Taylor and Rousseau"; and Marks, "Misreading one's sources."

6. Melzer, "Rousseau and the modern cult of sincerity," 279-80, 288.

7. Ibid., 279, 286. Cf. Griswold (a version of this paper is incorporated into Ch. 4 of Griswold's Jean-Jacques Rousseau and Adam Smith). 
8. Melzer, "Modern cult," for example, 274-6, 286.

9. Bloom, "Introduction," 4-5.

10. Melzer, "Modern cult," 282.

11. Rousseau, The Major Political Writings of Jean-Jacques Rousseau.

12. Ibid., 128. This would not, of course, be Rousseau's only response: see, for example, his note in Book II, Chapter 3 of the Social Contract, in the same volume.

13. Rousseau, Political Writings, 14.

14. Melzer, "Modern cult," 281-2, 285.

15. Rousseau, Political Writings, 128.

16. Melzer, "Modern cult," 284-5.

17. Here it might be objected that "love and esteem" are sought merely as a means of assuring our own power, but surely the reverse is also the case: we seek power as a means to love.

18. J.S. Mill, On Liberty and Other Essays, 65.

19. Melzer, "Modern cult," 274-5, 86; cf. 288.

20. Ibid., 280.

21. Trilling, Sincerity, 67; cf. 60 and 63.

22. In Emile (338) Rousseau approvingly cites the following passage from M. Duclos' Considerations sur les moeurs de ce siècle, which does not criticize adherence to social customs so much as the general absence of pro-social sentiment that ought to underlie such adherence: "The most unfortunate effect of formal politeness is to teach the art of getting along without the virtues it imitates. Let humanity and beneficence be inspired in us by education, and we shall have politeness, or we shall no longer need it."

23. See, for example, Rousseau, Political Writings, 13-14; on Rousseau's concerns about the popularization of the sciences and arts see Orwin, "Rousseau's Socratism."

24. Rousseau, Political Writings, 27. Rousseau uses Voltaire's given name in order to underscore his overriding desire for fame.

25. Rousseau, Letter to M. D'Alembert on the Theatre, 36, 47.

26. Ibid., 36-9.

27. See, for example, Rousseau, Emile, 212-15.

28. See, for example, Rousseau, Julie, or the New Heloise, 34.

29. Rousseau, Julie, 71. By "honor" Saint-Preux does not mean the aristocratic ideal that is "drawn from opinion" but rather an inwardly generated sense of self-worth "which derives from self-esteem" (Julie, 69).

30. Ibid., 275, 277-8.

31. Melzer, "Modern cult," 289.

32. Rousseau, Emile, 446-7.

33. Ibid., 448-9.

34. Ibid., 323-6.

35. Rousseau, Political Writings, 84.

36. Ibid. On the role of "false consciousness" in self-deception, see Griswold, "Selffalsification," 29, who views self-opacity as an obstacle to freedom. See also Ignatieff, The Needs of Strangers, 22; and Rosen, On Voluntary Servitude, 93.

37. Rousseau, in his capacity as editor (Julie, 316n.), cannot resist calling attention to Saint-Preux's disingenuousness: "[D]oes the author want nothing more than to be refuted?"

38. Rousseau, Julie, 312, emphasis added.

39. Ibid., 318.

40. Ibid., 316-17 and 316n.

41. Sackeim and Gur, "Self-deception, other-deception, and self-reported psychopathology"; Trivers, The Folly of Fools. See also Paulhus and Buckels, "Classic self-deception revisited."

42. Sackeim in Abumrad, "Self-deception"; Joanna Starek, "Self-deception and its relationship to success in competition."

43. See, for example, Strauss, 252-5; Masters, "Introduction," 21-4; Melzer, "Rousseau's moral realism"; Melzer, The Natural Goodness of Man. 
44. See, for example, Bloom, Love and Friendship; Yenor, Family Politics; and Warner, Rousseau and the Problem of Human Relations.

45. Rousseau, Emile, 329.

46. Ibid., 391.

47. For example, ibid., 212, 419.

48. For example, ibid., 424.

49. For example, ibid., 343; Rousseau, Political Writings, 232.

50. In this context (Emile, 320-5), the term "ancients" includes biblical and medieval European peoples as well as Greeks and Romans.

51. Rousseau, Emile, 321.

52. See, for example, Rousseau, Political Writings, 268; and Mostefai and Scott, Rousseau and L'Infame.

53. Warner, Rousseau, 65-9.

54. Scott, "Do you see what I see?"

55. Rousseau, Emile, 117, emphasis added.

56. Rousseau, Political Writings, 11, 51, 54.

\section{REFERENCES}

Abumrad, Jad. "Self-deception.” Radiolab, accessed August 18, 2016 at http:// www.radiolab.org/story/91618-lying-to-ourselves/.

Bell, Daniel. The Cultural Contradictions of Capitalism: 20th Anniversary Edition. New York: Basic Books, 1996.

Bloom, Allan. "Introduction.” In Jean-Jacques Rousseau, Emile, 3-28. New York: Basic Books, 1979.

Bloom, Allan. Love and Friendship. New York: Simon and Schuster, 1993.

Carpenter, Christopher. "Narcissism on Facebook: Self-promotional and antisocial behavior." Personality and Individual Differences 52 (2012): 482-6.

Cohen, Joshua. A Free Community of Equals. Oxford, UK: Oxford University Press, 2010.

Ferrara, Alessandro. Modernity and Authenticity: A Study on the Social and Ethical Thought of Jean-Jacques Rousseau. Albany, NY: SUNY Press, 1994.

Griswold, Charles. "Self-falsification, exchange, and freedom: Adam Smith and Jean-Jacques Rousseau in dialogue." Essay presented at "Adam Smith: Critic of Capitalism?" conference held at Yale University, April 10, 2015.

Griswold, Charles. Jean-Jacques Rousseau and Adam Smith, London: Routledge, 2018.

Ignatieff, Michael. The Needs of Strangers. New York: Picador, 2001.

Lasch, Christopher. The Culture of Narcissism. New York: Norton, 1991.

Marks, Jonathan. "Misreading one's sources: Charles Taylor's Rousseau." American Journal of Political Science 49 (2005): 119-34.

Masters, Roger. "Introduction.” In Jean-Jacques Rousseau, The First and Second Discourses, eds and trans. Judith and Roger Masters. Chicago, IL: University of Chicago Press, 1964.

Melzer, Arthur. "Rousseau's moral realism: Replacing natural law with the general will." American Political Science Review 77 (1983): 633-51.

Melzer, Arthur. The Natural Goodness of Man. Chicago, IL: University of Chicago Press, 1990. 
Melzer, Arthur. "Rousseau and the modern cult of sincerity." In The Legacy of Rousseau, eds Clifford Orwin and Nathan Tarcov, 274-95. Chicago, IL: University of Chicago Press, 1997.

Mill, J.S. On Liberty and Other Essays, ed. John Gray. Oxford, UK: Oxford University Press, 1998.

Mostefai, Ourida and John T. Scott. Rousseau and L'Infame: Religion, Toleration, and Fanaticism in the Age of Enlightenment. Leiden: Rodopi Press, 2009.

Orwin, Clifford. "Rousseau's Socratism." The Journal of Politics 60 (1998): 174-87.

Paulhus, Delroy L. and Erin Buckels. "Classic self-deception revisited." In Handbook of Self-Knowledge, eds Simine Vazire and Timothy D. Wilson, 363-78. New York: Guilford Press, 2012.

Rawls, John. Lectures on the History of Political Philosophy. Cambridge, MA: Belknap Press, 2007.

Reisert, Joseph. "Authenticity, justice, and virtue in Taylor and Rousseau." Polity 33 (2000): 305-30.

Rosen, Michael. On Voluntary Servitude: False Consciousness and the Theory of Ideology. Cambridge, MA: Harvard University Press, 1996.

Rousseau, Jean-Jacques. Letter to M. D'Alembert on the Theatre. In Politics and the Arts, ed. and trans. Allan Bloom. Glencoe, IL: Free Press, 1960.

Rousseau, Jean-Jacques. Emile: Or on Education. New York: Basic Books, 1979.

Rousseau, Jean-Jacques. The Confessions and Correspondence, eds Christopher Kelly, Roger Masters, and Peter Stillman, trans. Christopher Kelly. Hanover, NH: University Press of New England, 1995.

Rousseau, Jean-Jacques. Julie, or the New Heloise, eds Roger D. Masters and Christopher Kelly, trans. Phillip Stewart and Jean Vaché. Hanover, NH: University Press of New England, 1997.

Rousseau, Jean-Jacques. The Major Political Writings of Jean-Jacques Rousseau, ed. and trans. John Scott. Chicago, IL: University of Chicago Press, 2012.

Sackeim, Harold and Ruben Gur. "Self-deception, other-deception, and selfreported psychopathology." Journal of Consulting and Clinical Psychology 47 (1979): 213-15.

Scott, John T. "Do you see what I see? The education of the reader in Rousseau's Emile." The Review of Politics 74 (2012): 443-64.

Sennett, Richard. The Fall of Public Man. New York: Norton, 1992.

Starek, Joanna. "Self-deception and its relationship to success in competition." Basic and Applied Social Psychology 12 (1991): 145-55.

Strauss, Leo. Natural Right and History. Chicago, IL: University of Chicago Press, 1959.

Taylor, Charles. The Ethics of Authenticity. Cambridge, MA: Harvard University Press, 1993.

Trilling, Lionel. Sincerity and Authenticity: The Charles Eliot Norton Lectures. Cambridge, MA: Harvard University Press, 1970.

Trivers, Robert. The Folly of Fools: The Logic of Deceit and Self-Deception in Human Life. New York: Basic Books, 2011.

Twenge, Jean. Generation Me. Revised edition. New York: Atria, 2014. 
Warner, John. Rousseau and the Problem of Human Relations. College Park, PA: Penn State University Press, 2016.

Yenor, Scott. Family Politics. Waco, TX: Baylor University Press, 2011. 